\title{
METODE BOOKLET DIABETES MELITUS (DM) MENINGKATKAN KEPATUHAN PENYANDANG DM DALAM MANAJEMEN REGIMEN TERAPEUTIK
}

\author{
Dewi Murdiyanti Prihatin Putri ${ }^{1}$, Dwi Wulan Minarsih ${ }^{2}$ \\ ${ }^{1}$ Akademi Keperawatan YKY Yogyakarta \\ ${ }^{2}$ Akademi Keperawatan YKY Yogyakarta \\ Email : dewiputri4377@gmail.com
}

\begin{abstract}
ABSTRAK
Diabetes Melitus mengalami peningkatan angka kejadian setiap tahunnya. Diabetes Melitus merupakan penyakit kronis yang memiliki komplikasi yang terjadi secara sistemik yaitu terjadi kebutaan, penyakit jantung, stroke, gagal ginjal kronis, dan ulkus diebetes. Dari hasil survei kecil yang dilakukan di salah satu rumah sakit ditemukan data dari 10 orang penyandang Diabetes Melitus hanya 1 orang yang patuh terhadap manajemen regimen terapeutik Diabetes Melitus. Penyandang Diabetes harus merubah perilaku agar dapat terhindar dari komplikasi tersebut. Penelitian ini bertujuan untuk mengetahui apakah dengan metode booklet Diabetes Melitus dapat meningkatkan kepatuhan penyandang DM dalam manajemen regimen terapeutik. Penelitian ini merupakan penelitian cross sectional dengan menggunakan one group pre and post test design. Analisis data menggunakan Paired T-test. Berdasarkan hasil penelitian ini metode booklet ini mampu meningkatkan kepatuhan penderita Diabetes Melitus dalam manajemen regimen terapeutik terbukti dengan hasil analisis didapatkan probabilitas sebesar $0.001(\mathrm{p}<0.05)$ pada post tes pertama dan 0,000 ( $\mathrm{p}<0.05)$ pada post tes yang kedua. Simpulan dari penelitian ini adalah Booklet Diabetes dapat digunakan sebagai alat untuk membantu kegiatan edukasi yang harus terus diberikan oleh petugas kesehatan untuk mengingat kembali dan memonitor pelaksanaan regimen terapeutik penyandang DM.
\end{abstract}

Kata Kunci : Booklet, Diabetes Melitus, Kepatuhan

\begin{abstract}
Diabetes mellitus incidences were increased annually. Diabetes mellitus is a chronic disease that has systemic complications, i.e. blindness, heart disease, stroke, chronic renal failure, and ulcers diabetes. From the results of a small survey conducted in one hospital, it was found data that from 10 persons with Diabetes Mellitus, there was only one person obedient to the therapeutic regimens management of diabetes mellitus. Diabetics must change the behaviors in order to avoid such complications. This study aimed to determine whether the methods of Diabetes Mellitus booklet could improve the diabetic obedience to the therapeutic regimen management. This study was cross sectional study using one group of pre and post test design. The analysis of the data used paired Ttest. Based on the research results, the booklet method can improve the diabetics' obedience to the management of therapeutic regimens, it was proved by the analysis results that obtained the probability of $0.001(\mathrm{p}<0.05)$ in the first post test and the probability of $0.000(\mathrm{P}<0.05)$ in the second post-test. The conclusions from the research was that the diabetes booklet could be used as a tool to assist the educational activities that should be provided continously by the health workersto recall and monitor the implementation of the diabetic therapeutic regimens.
\end{abstract}

Keywords: Booklet, Diabetes Mellitus, Obedience. 


\section{PENDAHULUAN}

Diabetes Melitus merupakan gangguan metabolik yang ditandai dengan peningkatan kadar gula di dalam darah yang disebabkan karena kekurangan insulin, resistensi insulin maupun keduanya. Diabetes Melitus mengalami peningkatan angka kejadian setiap tahunnya. Diabetes Melitus merupakan penyakit kronis yang memiliki komplikasi yang terjadi secara sistemik yaitu terjadi kebutaan, penyakit jantung, stroke, gagal ginjal kronis, dan ulkus diebetes. Berdasarkan perhitungan dari Organisasi Kesehatan Dunia (WHO) pada tahun 2003, setidaknya ada 194 juta jiwa dari 3,8 miliyar penduduk dunia usia 20-79 tahun yang menderita Diabetes Melitus (DM), dan $80 \%$ diantaranya berada di negara berkembang, salah satunya adalah Negara Indonesia.

Dari hasil survei kecil yang dilakukan di salah satu rumah sakit ditemukan data dari 10 orang penyandang Diabetes Melitus hanya 1 orang yang patuh terhadap manajemen regimen terapeutik Diabetes Melitus. Penyandang Diabetes harus merubah perilaku agar dapat terhindar dari komplikasi tersebut. Merubah perilaku pada penyandang Diabetes tidak mudah, diperlukan motivasi yang diakukan secara terus menerus. Motivasi yang diperlukan dapat dengan berbagai cara salah satunya dengan memberikan edukasi untuk selalu mengingatkan tentang perawatan penyandang Diabetes Melitus (4 pilar) setiap saat. Edukasi yang diberikan secara langsung sudah sering dilakukan dan sering penyandang lupa dengan apa yang sudah disampaikan, sehingga diperlukan suatu media yang dapat selalu mengingatkan penyandang tentang perawatan Diabetes Melitus (4 pilar) yang dapat dibawa kemanapun pergi dan dimanapun berada. Metode booklet merupakan salah satu media untuk memberikan edukasi dan mengingatkan penyandang Diabetes Melitus tentang perawatan Diabetes Melitus (4 pilar). Penelitian ini memberikan jalan dikeluarkannya suatu booklet yang berisi 4 pilar perawatan Diabetes Melitus yang bertujuan untuk memfasilitasi penyandang untuk selalu mengingat tentang perawatan Diabetes Melitus dimanapun dan kapanpun sehingga dapat merubah perilaku penyandang Diabetes Melitus dan terhindar dari komplikasi bahkan dari kematian.

\section{KAJIAN LITERATUR}

Diabetes melitus sampai saat ini dikenal sebagai suatu gangguan metabolik yang ditandai dengan hiperglikemi kronis dengan gangguan metabolisme karbohidrat, lemak dan protein yang disebabkan karena penurunan produksi insulin, penurunan kerja insulin atau keduanya (Alberti, 2010). Diabetes melitus merupakan masalah kesehatan yang serius di dunia dan sampai saat ini diabetes melitus masih diderita banyak orang dan prevalensinya terus mengalami peningkatan (Michel, 2011). Klasifikasi diabetes melitus berdasarkan penyebab dibagi menjadi 4 jenis, yaitu diabetes melitus tipe 1 (DMT1), diabetes melitus tipe 2 (DMT2), diabetes gestasional dan diabetes melitus tipe lain (Fain, 2009). Diabetes melitus tipe 2 dialami sekitar 80 90\% dari jumlah seluruh penyandang diabetes melitus (Laakso, 2008). Berdasarkan konsensus PERKENI tahun 2011 penatalaksanaan diabetes yang ada di Indonesia secara umum diarahkan untuk meningkatkan kualitas hidup pasien diabetes melitus. Penatalaksanaan awal (jangka pendek) dilakukan untuk menghilangkan keluhan dan tanda DM, mempertahankan rasa nyaman dan mencapai target pengendalian glukosa darah. Penatalaksanaan berikutnya (jangka panjang) adalah mencegah dan menghambat progresivitas penyulit mikroangiopati, makroangiopati dan neuropati.

Edukasi diabetes telah menjadi komponen yang penting dari manajemen diabetes sejak tahun 1930 dan meningkat dikenal sebagai bagian integral dari manajemen penyakit kronis. Tujuan dari edukasi pada pasien DMT2 yaitu untuk mengoptimalisasi kontrol 
metabolik, mencegah komplikasi baik akut maupun kronis, meningkatkan kualitas hidup dengan mempengaruhi pengetahuan, sikap dan perilaku menjadi sehat (Atak, Gurkan \& Kose, 2009). Perilaku kepatuhan sering diartikan sebagai usaha pasien untuk mengendalikan perilakunya. Bahkan jika tidak dilakukan hal tersebut bisa menimbulkan resiko mengenai kesehatannya, faktor penting ini sering dilupakan banyak pasien. Edukasi untuk merubah perilaku dapat dilakukan dengan berbagai metode. Booklet merupakan media untuk menyampaikan pesan dalam bentuk buku, baik tulisan maupun gambar. Kelebihan Individu dapat lebih jelas menerima informasi karena dilengkapi tulisan dan gambar. Selain itu, design bisa lebih menarik disesuaikan dengan sasaran. Kekurangan Biaya pembuatan agak sedikit lebih banyak daripada pembuatan leaflet (Notoadmojo, 2003). Berdasarkan uraian tersebut penelitian ini bertujuan untuk mengetahui apakah dengan metode booklet Diabetes Melitus dapat meningkatkan kepatuhan penyandang DM dalam manajemen regimen terapeutik.

\section{METODE PENELITIAN}

Rancangan penelitian menggunakan rancangan cross sectional dengan menggunakan one group pre and post test design. Analisis data menggunakan Paired T- test. Sebelum pemberian booklet kepada penyandang DM dilakukan penyebaran kuesioner dan mengobservasi tingkat kepatuhan penyandang DM dalam manajemen regimen terapeutik. Kemudian dilakukan pendidikan kesehatan tentang 4 pilar perawatan Diabetes Melitus yang sesuai dengan isi booklet, setelah itu dilanjutkan dengan pemberian Booklet Diabetes Melitus kepada penyandang DM . Setelah 2 bulan pertama pemberian booklet kemudian dilakukan observasi kembali dan penyebaran kuesioner adanya peningkatan tingkat kepatuhan penyandang DM dalam manajemen regimen terapeutik. Kemudian 2 bulan kedua setelah pemberian booklet dilakukan evaluasi dengan penyebaran kuesioner adanya peningkatan tingkat kepatuhan penyandang DM dalam manajemen regimen terapeutik.

\section{HASIL DAN PEMBAHASAN}

Total jumlah responden yang menderita DM yang menjadi sampel dalam penelitian ini berjumlah 50 orang yang diambil saat datang menghadiri kegiatan olah raga tiap hari Jumat. Karakteristik responden dalam penelitian ini meliputi usia, jenis kelamin, lama menderita DM, Indeks Masa Tubuh, Gula Darah Puasa, Tekanan darah dan Lingkar Perut.

Tabel 1. Distribusi Batasan Karekteristik Responden Berdasarkan Usia, Jenis Kelamin Lama DM, Indeks Massa Tubuh (IMT), Gula Darah Puasa (GDP), Tekanan

Darah (TD) dan Lingkar Perut (LP) Pada Penyandang DM di PERSADIA Kota Yogyakarta Tahun 2016

\begin{tabular}{clcc}
\hline No & Kriteria & Jumlah & $\begin{array}{c}\text { Prosentase } \\
(\boldsymbol{\%})\end{array}$ \\
\hline 1 & Umur & 5 & 10 \\
& $<55$ th & 44 & 88 \\
& $55-80$ th & 1 & 2 \\
\hline & $>80$ th & & \\
\hline 2 & Jenis Kelamin & 10 & 20 \\
& Laki-laki & 40 & 80 \\
\hline & Perempuan & & \\
3 & Lama Menderita DM & 3 & 6 \\
& $<5$ th & 41 & 82
\end{tabular}




\begin{tabular}{|c|c|c|c|}
\hline & $>20$ th & 6 & 12 \\
\hline \multirow[t]{4}{*}{4} & Indeks Masa Tubuh (IMT) & & \\
\hline & Normal $(18-24)$ & 31 & 62 \\
\hline & Over weight $(25-30)$ & 17 & 34 \\
\hline & Obesitas $(31-40)$ & 2 & 4 \\
\hline \multirow[t]{4}{*}{5} & Gula darah Puasa (GDP) & & \\
\hline & $<70 \mathrm{gr} / \mathrm{dL}$ & 1 & 2 \\
\hline & $70-125 \mathrm{gr} / \mathrm{dL}$ & 25 & 50 \\
\hline & $>125 \mathrm{gr} / \mathrm{dL}$ & 24 & 48 \\
\hline \multirow[t]{4}{*}{6} & Tekanan Darah (TD) & & \\
\hline & Pre Hipertensi & 37 & 74 \\
\hline & HT Stadium 1 & 6 & 12 \\
\hline & HT Stadium 2 & 7 & 14 \\
\hline \multirow[t]{5}{*}{7} & Lingkar Perut (LP) & & \\
\hline & Laki-laki : <90 cm & 6 & 60 \\
\hline & $\geq 90 \mathrm{~cm}$ & 4 & 40 \\
\hline & Perempuan : $<80 \mathrm{~cm}$ & 8 & 20 \\
\hline & $\geq 80 \mathrm{~cm}$ & 32 & 80 \\
\hline
\end{tabular}

Apabila ditinjau dari umur, penelitian ini menunjukkan bahwa responden yang memiliki umur $\geq 55$ tahun merupakan responden dengan persentase paling besar (90 \%). Hal ini sejalan dengan hasil penelitian Awad (2011) yang menunjukkan peningkatan jumlah pasien DM Tipe 2 pada pasien yang berumur lebih dari 50 tahun. Hasil Riskesdas tahun 2007 juga menunjukkan bahwa jumlah penderita DM di Indonesia semakin meningkat seiring dengan meningkatnya umur. Prevalensi DM akan semakin meningkat seiring dengan makin meningkatnya umur, hingga kelompok usia lanjut (Bustan, 2007). Hal tersebut sesuai dengan penelitian Wild, dkk (2004) tentang prevalensi DM secara global yang menunjukkan bahwa semakin meningkatnya umur, semakin tinggi pula prevalensi DM yang ada.

Pada penelitian ini jumlah responden yaitu 50 penyandang DM di PERSADIA Kota Yogyakarta yang terdiri dari 10 responden $(20 \%)$ laki-laki dan 40 responden $(80 \%)$ perempuan. Hal ini sesuai dengan hasil penelitian Lubis (2012) dan Bintanah (2012) yang menunjukkan bahwa penderita DM Tipe 2 lebih banyak terjadi pada perempuan dibandingkan laki-laki.

Penyandang DM di Persadia Kota Yogyakarta sebagian besar menderita DM 5
- 20 tahun, sebagian besar memiliki IMT normal (62\%) dan gula darah puasa normal $(50 \%)$.

Penelitian ini sejalan dengan penelitian yang dilakukan oleh Ninh T. Nguyen, Xuan-Mai T Nguyen, John Lane, dan Ping Wang (2011) yang menunjukkan bahwa adanya hubungan yang signifikan antara IMT dan terjadinya resisten insulin yang menyebabkan kenaikan kadar gula darah puasa. Hal ini berarti semakin besar nilai indeks massa tubuh (IMT), semakin besar pula nilai gula darah puasanya. Pada penelitian ini menunjukan bahwa sebagian besar responden memiliki IMT normal diikuti pula dengan GPD yang normal pula.

Pada data penelitian ini ditemukan responden yang termasuk ke dalam kategori overweight dan obesitas sebanyak 19 orang (38\%). Hal ini tidak sejalan dengan teori Suyono (2011), bahwa faktor risiko dari diabetes melitus tipe 2 adalah faktor kegemukan/ obesitas yang meliputi perubahan gaya hidup dari tradisional ke gaya hidup barat, makan berlebihan, dan hidup santai (kurang gerak). Hal ini terjadi karena responden memiliki lama menyandang DM yang rata-rata lebih dari 5 tahun maka dimungkinkan responden dapat mengontrol pola makan sesuai anjuran petugas kesehatan. 
Pada penelitian ini ditunjukkan data bahwa sebagian besar responden berada pada kondisi prehipertensi yaitu sebanyak 37 orang $(74 \%)$. Hipertensi pada DM tipe 2 muncul bersamaan dengan atau mungkin malah mendahului munculnya diabetes. Hal ini disebabkan pada penderita hipertensi sering ditemukan adanya sekumpulan kelainan lainnya seperti: obesitas sentral, dislipidemi, hiperurisemi dan hiperinsulinemia/resistensi insulin atau yang sekarang disebut sindroma metabolik. Dalam penelitian ini, orang yang memiliki riwayat hipertensi lebih berisiko terkena DM tipe-2 dibandingkan dengan orang yang tidak memiliki riwayat hipertensi meskipun secara datanya banyak yang berada di prehipertensi.

Hal ini disebabkan karena selama menyandang DM tekanan darah sudah terus dipantau sehingga sedikit terkontrol dan masuk kedalam prehipertensi. Hal ini juga sesuai dengan penelitian sebelumnya di Amerika yang menunjukkan bahwa individu dengan hipertensi 2,5 kali lebih sering mengalami DM tipe-2 dibanding normotensi. Hasil penelitian ini menunjukkan data responden perempuan yang memiliki lingkar perut diatas $80 \mathrm{~cm}$ sebanyak 32 orang $(80 \%)$, hal ini sejalan dengan penelitian yang dilakukan oleh Soetiarto dkk (2010) yang menemukan bahwa obesitas sentral berdasarkan lingkar perut berperan sebagai faktor resiko terjadinya DM 2,26 kali dari yang tidak obes sentral.

\section{Perbedaan Kepatuhan Sebelum dan setelah diberikan booklet pada post tes 2 bulan pertama}

Setelah dilakukan pre tes dan post tes untuk 2 bulan pertama tentang penatalaksanaan Diabetes Melitus kepada responden didapatkan hasil bahwa terdapat perbedaan nyata dengan adanya perlakuan pemberian booklet kepada responden setelah 2 bulan kemudian.

Tabel 2. Data Perbedaan Hasil Observasi Tingkat Kepatuhan Sebelum dan Sesudah diberi Booklet 2 Bulan Pertama Pada Penyandang DM di Persadia Kota Yogyakarta Tahun 2016

\begin{tabular}{lcccc}
\hline \multicolumn{1}{c}{ Kepatuhan } & N & Rata-rata & Beda Rata-rata & P \\
\cline { 1 - 2 } PRE & 50 & 2,2800 & 0,30 & 0,001 \\
\hline POST I & 50 & 2,5800 & & \\
\hline
\end{tabular}

Dengan menggunakan uji $\mathrm{t}$ untuk kelompok berpasangan diperoleh hasil ratarata kepatuhan responden adalah 2,28 sedangkan setelah 2 bulan diberikan booklet menunjukkan peningkatan rata-rata menjadi 2,58. Selisih rata-rata tingkat kepatuhan adalah sebesar 0,30 yang signifikan yaitu dengan angka probabilitas 0,001 .

Peningkatan kepatuhan diawali dengan adanya peningkatan pengetahuan penyandang DM tentang 4 pilar penatalaksanaan DM yang harus diketahui. Hasil penelitian ini sesuai dengan hasil penelitian Malikatul (2015) yang menyatakan bahwa pendidikan kesehatan menggunakan media booklet dapat meningkatkan pengetahuan. Booklet merupakan alat bantu berbentuk buku, dilengkapi dengan tulisan maupun gambar yang disesuaikan dengan sasaran pembacanya. Informasi yang ada dalam booklet disusun dengan jelas dan rinci sehingga dapat ditangkap dengan baik oleh sasaran pendidikan dan tidak menimbulkan kesalahan persepsi. Penggunaan media booklet sebagai alat bantu dalam pemberian edukasi kepada penyandang DM, akan membuat sasaran pendidikan lebih mudah memahami informasi yang disampaikan dibandingkan penyampaian informasi hanya secara lisan, karena sasaran pendidikan dapat mengamati langsung gambar dan tulisan yang merupakan penjelasan terhadap gambar yang ada dalam media tersebut. 
2. Perbedaan Kepatuhan Sebelum dan setelah diberikan booklet post tes 2 bulan kedua

Setelah dilakukan pre tes dan post tes untuk 2 bulan kedua tentang penatalaksanaan
Diabetes Melitus kepada responden didapatkan hasil bahwa terdapat perbedaan nyata dengan adanya perlakuan pemberian booklet kepada responden setelah 4 bulan kemudian.

Tabel 3. Data Perbedaan Hasil Observasi Tingkat Kepatuhan sebelum diberikan Booklet dan 2 bulan Kedua Setelah diberi Booklet Pada Penyandang DM di Persadia

Kota Yogyakarta Tahun 2016

\begin{tabular}{lcccc}
\multicolumn{5}{c}{ A. } \\
\cline { 1 - 2 } Kepatuhan & $\mathrm{N}$ & Rata-rata & Beda Rata-rata & P \\
\cline { 1 - 2 } PRE & 50 & 2,2800 & 0,420 & 0,000 \\
\hline POST II & 50 & 2,700 & & \\
\hline
\end{tabular}

Dengan menggunakan uji $\mathrm{t}$ untuk kelompok berpasangan diperoleh hasil ratarata kepatuhan responden adalah 2,28 sedangkan setelah 2 bulan kedua setelah diberikan booklet menunjukkan peningkatan rata-rata menjadi 2,70. Selisih rata-rata tingkat kepatuhan adalah sebesar 0,420 yang signifikan yaitu dengan angka probabilitas 0,000 .

Pendidikan kesehatan dengan media atau alat peraga dapat mengubah pengetahuan melalui pancaindera yang ditangkap oleh seseorang. Media atau alat peraga adalah alat yang digunakan oleh pendidik untuk membantu dan menerangkan sesuatu dalam proses pendidikan atau pengajaran. Media bermanfaat menimbulkan minat sasaran, merangsang sasaran untuk meneruskan pesan pada orang lain, dan memudahkan penyampaian informasi. Media booklet adalah buku yang tipis dan lengkap informasinya, yang memudahkan media tersebut untuk dibawa (Satmoko dkk, 2006). Booklet berisi informasi yang jelas, tegas dan mudah dimengerti selain itu juga berisi tulisan dan gambar (Suiraoka \& Supariasa, 2012). Hal tersebut sesuai dengan penelitian yang dilakukan oleh Wibowo (2013) bahwa ada pengaruh pengetahuan responden setelah dilakukan pendidikan kesehatan dengan metode buku saku/booklet.

\section{Perbedaan Kepatuhan setelah} diberikan booklet pada 2 Bulan pertama dan post tes 2 bulan kedua

Setelah dilakukan post tes 2 bulan pertama dan post tes untuk 2 bulan kedua tentang penatalaksanaan Diabetes Melitus kepada responden didapatkan hasil bahwa terdapat perbedaan nyata dengan adanya perlakuan pemberian booklet kepada responden setelah pengamatan selama 4 bulan.

Tabel 4. Data Perbedaan Hasil Observasi Tingkat Kepatuhan setelah diberikan Booklet pada 2 bulan pertama dan Kedua Penyandang DM di Persadia Kota Yogyakarta Tahun 2016

\begin{tabular}{lcccc}
\hline Kepatuhan & $\mathrm{N}$ & Rata-rata & Beda Rata-rata & P \\
\cline { 1 - 3 } POST I & 50 & 2,580 & 0,120 & 0,032 \\
\hline POST II & 50 & 2,700 & & \\
\hline
\end{tabular}

Dengan menggunakan uji $\mathrm{t}$ untuk kelompok berpasangan diperoleh hasil ratarata kepatuhan responden pada 2 bulan pertama adalah 2,58 sedangkan setelah 2 bulan kedua setelah diberikan booklet menunjukkan peningkatan rata-rata menjadi
2,70. Selisih rata-rata tingkat kepatuhan adalah sebesar 0,120 yang signifikan yaitu dengan angka probabilitas 0,032 .

Berdasarkan hasil tersebut peningkatan kepatuhan pada penyandang Diabetes Melitus terjadi setelah pemberian 
booklet Diabetes dan dilakukan pengamatan pada 2 bulan pertama dan 2 bulan kedua. Hal ini sesuai dengan pernyatan Lailatushifah, 2012 yang menyatakan bahwa cara meningkatkan kepatuhan individu diantaranya adalah memberikan informasi kepada pasien akan manfaat dan pentingnya kepatuhan untuk mencapai keberhasilan pengobatan, memberikan informasi tentang resiko ketidakpatuhan dan mengingatkan pasien untuk melakukan segala sesuatu yang harus dilakukan demi keberhasilan pengobatan dengan alat komunikasi. Alat komunikasi tersebut salah satunya dapat berupa booklet.

\section{Gambaran Peningkatan Kepatuhan Penyandang DM}

Prosentase kepatuhan Penyandang DM mengalami peningkatan. Hal ini ditunjukkan dengan adanya peningkatan prosentase antara post tes I dan II dengan gambaran tingkat kepatuhan rendah menjadi berkurang yaitu menjadi $0 \%$ dan tingkat kepatuhan sengan mengalami penurunan sebesar $12 \%$ dan tingkat kepatuhan tinggi meningkat sebesar $12 \%$.

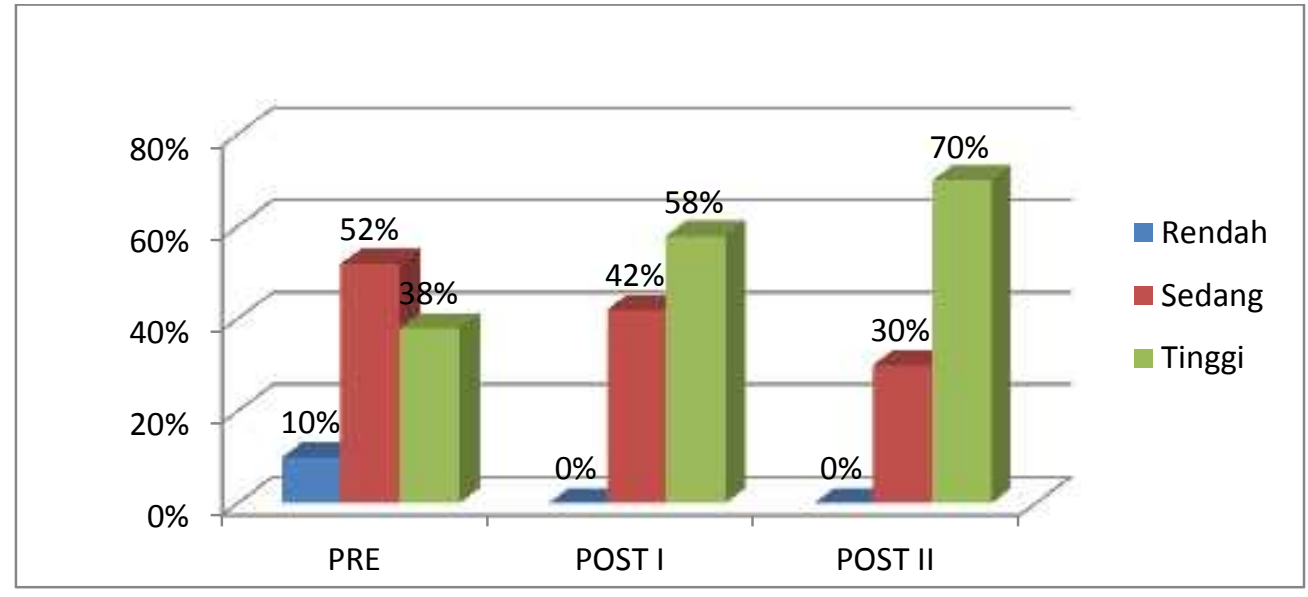

Gambar 1. Grafik Prosentase Peningkatan Kepatuhan Pada Penyandang DM di PERSADIA Kota Yogyakarta Tahun 2016

Setelah dilakukan Post tes I dan Post Tes II didapatkan adanya peningkatan kepatuhan yang signifikan dengan selisih beda rata-rata sebesar 0,120 , yang ditunjukkan melalui grafik peningkatan kepatuhan Penyandang DM di bawah ini.

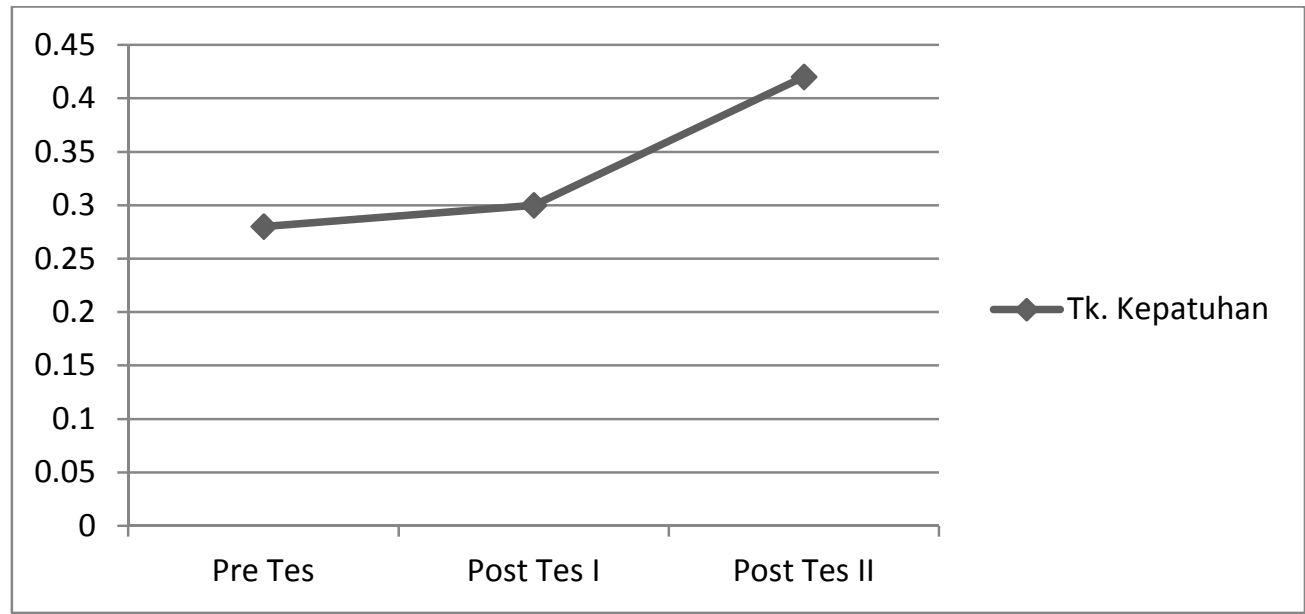




\section{Gambar 2. Grafik Beda Rata-rata Peningkatan Kepatuhan Pada Penyandang DM di PERSADIA Kota Yogyakarta Tahun 2016}

Dari gambar tersebut di atas menunjukkan adanya peningkatan yang signifikan penyandang DM sebelum diberikan booklet dengan setelah diberikan booklet (post tes I dan post tes II). Hal ini diperkuat pula dengan adanya data semua responden mengisi komitmen kepatuhan dan data pemeriksaan yang ada dalam booklet.

Pendidikan kesehatan yang disampaikan melalui metode atau media booklet dapat mempengaruhi individu baik pengetahuan, sikap dan perilaku sesuai dengan tujuan dari pendidikan kesehatan tersebut dan pemilihan metode atau media yang tepat atau efektif diperlukan untuk menyampaikan informasi yang tepat. hasil penelitian ini menunjukkan bahwa pemberian informasi melalui booklet berpengaruh signifikan meningkatkan tingkat kepatuhan penyandang DM. Hal ini sesuai dengan pernyataan Rogers yang mengatakan bahwa penerimaan perilaku yang didasari oleh pengetahuan dan sikap yang positif (membentuk kepatuhan), maka perilaku tersebut akan bertahan lama. Tetapi sebaliknya, jika perilaku yang tidak didasari dengan pengetahuan dan sikap yang positif maka perilaku tersebut tidak bertahan lama.

\section{KESIMPULAN DAN SARAN \\ Kesimpulan}

Metode booklet ini efektif untuk meningkatkan kepatuhan penyandang DM dengan ukuran booklet yang kecil memudahkan untuk dibawa kemana-mana disertai dengan desain yang penuh warna dan tulisan yang jelas menambah daya tarik penderita Diabetes Melitus untuk selalu membawa dan membacanya. Booklet ini dapat digunakan sebagai alat untuk membantu kegiatan edukasi yang harus terus diberikan oleh petugas kesehatan untuk mengingat kembali dan memonitor pelaksanaan regimen terapeutik penyandang DM.

Saran

Kepada Penyandang DM anggota PERSADIA untuk selalu membawa dan membaca booklet yang sudah didapatkan ini untuk dapat mengingatkan dan memonitor manajemen regimen terapeutik penyandang DM.

\section{DAFTAR PUSTAKA}

Alberti, K. .M. M. (2010). The Classification and Diagnosis of Diabetes Mellitus. Dalam Holt, R.I.G., Cockram, C., Flyvbjerg, A., \& Goldstein, J. (Editor). Textbook of Diabetes. $4^{\text {th }}$ Edition. Willey-Blackwell Ltd.

Atak, N., Gurkam, T., \& Kose, K. (2009). The Effect of Education on Knowledge, self Management Behaviours and Self Efficacy of Patients With Type 2 Diabetes. Australian Journal of Advanced Nursing. Volume 26 number 2.

Awad, N., Langi, Y., dan Pandelaki, K. 2011. Gambaran Faktor Resiko Pasien Diabetes Melitus Tipe II Di Poliklinik Endokrin Bagian/Smf FkUnsrat Rsu Prof.Dr. R.D Kandou Manado Periode Mei 2011 - Oktober 2011 (Skripsi). Universitas Sam Ratulangi, Manado

Bintanah, S. dan Handarsari, E. 2012. Asupan Serat Dengan Kadar Gula Darah, Kadar Koleterol Total dan Status Gizi Pada Pasien DM Tipe 2 Di Rumah Sakit Roemani Semarang. Jurnal Unimus: Seminar Hasil-Hasil Penelitian. Hal. 289-297.

Bustan, M.N. 2007. Epidemiologi Penyakit Tidak Menular. Jakarta: Rineka Cipta

Fain., (2009). Management of Clients with Diabetes Mellitus. Dalam J.M.Black \& J.H Hawks (Editor). MedicalSurgical Nursing ; Clinical Management for Positive Outcomes 
eight edition Vol.1 Sounders. Elsevier Mosby.

Lailatushifah, S.N. F., 2012. Kepatuhan Pasien Yang Menderita Penyakit Kronis Dalam Mengkonsumsi Obat Harian. http://fpsi.mercubuanayogya.ac.id/wpcontent/uploads/2012/06/Noor-

Kepatuhan...pdf/ Diakses tanggal 3 Desember 2016

Laakso, M. (2008). Epidemiology of Type 2 Diabetes dalam Goldstein, B.J \& Muller-Wieland, D . Type 2 Diabetes. Principles and Practice. Second Edition. Informa Healthcare. New York. London.

Lubis, J. P. 2012. Perilaku Penderita Diabetes Melitus Rawat Jalan di RSUD Rantauprapat Kabupaten Labuhanbatu Dalam Pengaturan Pola Makan. (Skripsi). Universitas Sumatera Utara.

Malikatul M. Pengaruh pendidikan kesehatan dengan booklet terhadap pengetahuan nutrisi ibu laktasi di wilayah kerja puskesmas Ciputat Timur. Fakultas Ilmu Kesehatan Universitas Muhammadiyah Surakarta. Naskah publikasi. 2015 [cited 9 November 2016]. Available from: http://lib.ui.ac.id/file?file =digital/125716-R17-PER-216\%20-

Perbandingan\%-

20efektivitasMetodologi.pdf.

Michel, B. (2011). Nursing management diabetes mellitus. Dalam S. Lewis, S. Dirksen, M. Heitkemper, L. Bucher, \& I. Camera (Editor), Medical surgical nursing eight edition vol 2 chapter 49. USA: Elsevier Mosby.

Ninh T. Nguyen, Xuan-Mai T Nguyen, John Lane, dan Ping Wang (2011) . Relationship Between Obesity and Diabetes in a US Adult Population: Findings from the National Health and Nutrition Examination Survey, 1999-2006.

Notoatmodjo, S. (2003). Pendidikan dan Perilaku kesehatan. Jakarta PT Rineka Cipta.

Perkeni. (2011) . Konsensus Pengelolaan dan Pencegahan Diabetes Melitus Tipe 2 di Indonesia 2011. Perkumpulan Endokrinologi Indonesia.

Satmoko, Sriroso \& dan Astuti, Harini T. (2006). Pengaruh Bahasa Booklet Pada Peningkatan Pengetahuan Peternak Sapi Perah tentang Inseminasi Buatan di Kelurahan Nongkosawit, Kecamatan Gunungpati Kota Semarang. Jurnal Penyuluhan ISSN: 1858- 2664, vol. 2. No.2

Soetiarto F, Roselinda, dam Suhardi. (2010). Hubungan Diabetes Melitus dengan Obesitas Berdasarkan Indeks Massa Tubuh dan Lingkar Pinggang. Buletin Penelitian Kesehatan.

Suiraoka, I Putu., \& Supariasa, I Dewa Nyoman. (2012). Media Pendidikan Kesehatan. Yogyakarta: Graha Ilmu.

Suyono. S (2011). Patofisiologi Diabetes Melitus dalam Buku Penatalaksanaan Diabetes Terpadu . Jakarta : Fakultas Kedokteran Universitas Indonesia.

Wibowo, Surya \& Suryani, Dyah. (2013). Pengaruh Promosi Kesehtan Metode Audiovisual Dan Metode Efektifitas pendidikan kesehatan media booklet dibandingkan dengan audiovisual terhadap pengetahuan orangtua tentang karies gigi pada anak usia 59 tahun di desa makamhaji (Maria Agustin) Buku Saku Terhadap Peningkatan Pengetahuan Penggunaan Monosodium Glutamat (MSG) Pada Ibu Rumah Tangga. Jurnal Kesmas ISSN: 1978-0575, Vol.7 No.2. Http://lib.ugm.ac.id. 
Diakses tanggal 2 bulan November 2013.

Wild, S., Roglic, G., Green, A., Sicree, R., \& King, H. (2004). Global prevalence of diabetes: estimates for the year 2000 and projections for 2030. Diabetes Care. 2004 May;27(5):1047-53.

PMID:15111519. 